Note

\section{An Assay for Serine-glyoxylate Aminotransferase}

\author{
Yoshikazu IzumI, ${ }^{1}$ Toyokazu Yoshida ${ }^{2}$ \\ and Hideaki YamaDA
}

Department of Agricultural Chemistry, Faculty of Agriculture, Kyoto University. Kyoto 606, Japan

Received October 19, 1989 sodium glyoxylate were from Sigma Co. (U.S.A.). NADH was from Oriental Yeast Co. (Japan). All other chemicals used were from commercial sources and of reagent grade. Absorbance measurements were made with a Shimadzu UV-240 spectrophotometer (Japan).

We first examined the concentration of Tris as a trapping reagent for glyoxylate. The reaction mixture contained various amounts of Tris/HCl buffer ( $\mathrm{pH} 8.0$ ), $0.13 \mu \mathrm{mol}$ of NADH, 0.085 units of HPR, and $5 \mu \mathrm{mol}$ of glyoxylate or $1 \mu \mathrm{mol}$ of hydroxypyruvate in a final volume of $1 \mathrm{ml}$. The reaction was done at $30^{\circ} \mathrm{C}$ and the rate of glyoxylate reduction was measured by monitoring the decrease in absorbance at $340 \mathrm{~nm}$. The reduction of glyoxylate $(5 \mathrm{~mm})$ was suppressed completely in $200 \mathrm{~mm}$ Tris/ $\mathrm{HCl}$ buffer. In contrast, the added hydroxypyruvate

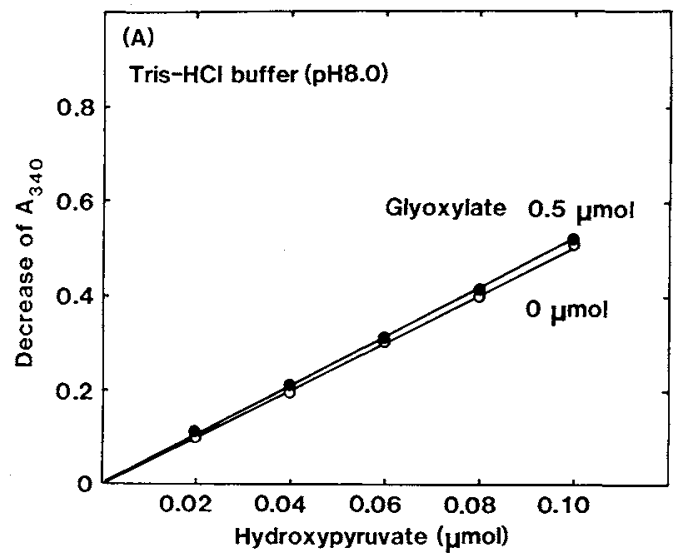

Serine-glyoxylate aminotransferase (SGAT, EC 2.6. 1.45) has been studied with various organisms. In the liver, ${ }^{1.2)}$ SGAT is reported to have a wide substrate specificity. In plants, ${ }^{3-5}$ this enzyme is involved in the photorespiratory glycolate pathway. In microorganisms, SGAT is an enzyme specific for the serine pathway of methylotrophic bacteria. ${ }^{6.7}$ We previously reported on Lserine production by Hyphomicrobium methylovorum GM2, which has this pathway, ${ }^{81}$ and we purified and characterized some enzymes in the serine pathway. ${ }^{9-11}$ However, the activity of SGAT was not detected by the coupling method generally used, suggesting that this method is unsuitable in practice.

Coupling methods using D-glycerate dehydrogenase (EC 1.1.1.29), ${ }^{4}$ lactate dehydrogenase (LDH, EC 1.1 .1 .27$),{ }^{2.12)}$ and a cellfree extract containing hy-

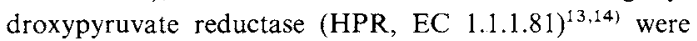
reported for the SGAT assay. However, these assay methods are fairly inaccurate because the coupling enzymes also reduce the glyoxylate added as a substrate other than hydroxypyruvate, a reaction product of SGAT. Another assay method ${ }^{2)}$ using $\mathrm{LDH}$ under conditions in which the remaining glyoxylate is trapped with Tris by forming a stable Shiff base ${ }^{15 /}$ has been reported. However, this method has not been examined in detail, and LDH is considered to be unsuitable due to its substrate specificity and the significant activity of the reverse reaction.

We have purified HPR from H. methylovorum GM2, which has a high substrate specificity (the $K m$ for hydroxypyruvate and glyoxylate are 0.175 and $10.8 \mathrm{~mm}$, respectively) and reduces hydroxypyruvate irreversibly (Izumi et al., unpublished results). Therefore, this HPR appears to be suitable for the SGAT assay. This report deals with the establishment of an SGAT assay using HPR from this bacterium.

The HPR used here was the purified preparation from H. methylovorum GM2. Lithium hydroxypyruvate and

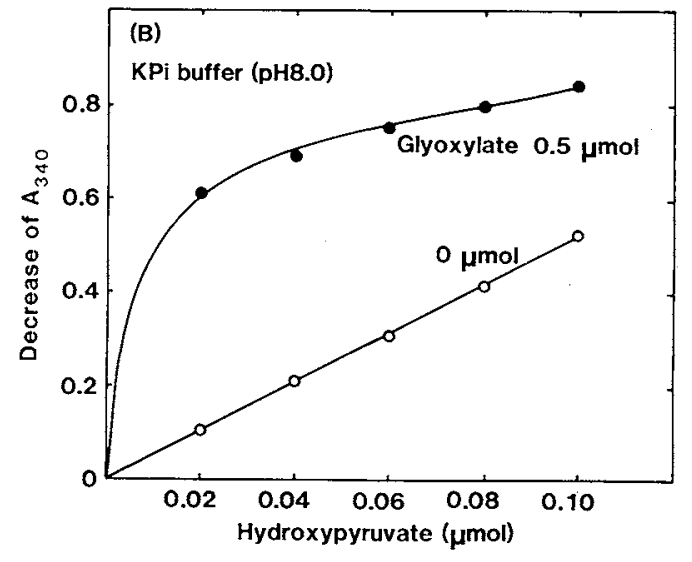

Fig. 1. Effects of Buffers on the Measurement of $\mathrm{Hy}$ droxypyruvate.

The measurements of hydroxypyruvate were done by Reaction 2 in $200 \mathrm{~mm}$ Tris/HCl buffer, $\mathrm{pH} 8.0$ (A) or $100 \mathrm{~mm}$ potassium phosphate buffer (KPi buffer), $\mathrm{pH} 8.0$ (B).

\footnotetext{
1 Present address: Department of Biotechnology, Faculty of Engineering, Tottori University, Tottori 680, Japan

2 Present address: Department of Food and Nutrition, Faculty of Agriculture, Kinki University, Nara 631, Japan.
} 
was reduced measurably, although the initial reaction rate was less than one-fifth that in $100 \mathrm{~mm}$ potassium phosphate buffer ( $\mathrm{pH} 7.0)$.

The standard assay procedure was established as follows. Reaction 1 (SGAT reaction): the reaction mixture contained $100 \mu \mathrm{mol}$ of potassium phosphate buffer $(\mathrm{pH}$ $7.0), 20 \mu \mathrm{mol}$ of $\mathrm{L}$-serine, $5 \mu \mathrm{mol}$ of sodium glyoxylate, $0.1 \mu \mathrm{mol}$ of pyridoxal 5 -phosphate, and an appropriate amount of the enzyme solution in a final volume of $1 \mathrm{ml}$. A control reaction was done without the enzyme solution. The reaction was done at $30^{\circ} \mathrm{C}$ for $10 \mathrm{~min}$, stopped by addition of $0.1 \mathrm{ml}$ of $1 \mathrm{~N} \mathrm{HCl}$, and centrifuged. Reaction 2 (hydroxypyruvate measurement): the reaction mixture contained $0.1 \mathrm{ml}$ of the above solution (or the standard hydroxypyruvate solution), $200 \mu \mathrm{mol}$ of Tris/ $\mathrm{HCl}$ buffer (pH 8.0), $0.15 \mu \mathrm{mol}$ of $\mathrm{NADH}$, and 1 unit of HPR in a final volume of $1 \mathrm{ml}$. After the reaction went at $30^{\circ} \mathrm{C}$ for $30 \mathrm{~min}$, the decrease in absorbance at $340 \mathrm{~nm}$ was measured. The activity of SGAT is calculated from the amount of hydroxypyruvate formed in Reaction 1. using the standard curve obtained in Reaction 2.

We then studied the effects of Tris on the standard curve for hydroxypyruvate (Reaction 2) in the presence of glyoxylate (Fig. 1). In Tris/ $\mathrm{HCl}$ buffer, similar linear standard curves for hydroxypyruvate were obtained both in the presence and absence of glyoxylate. In potassium phosphate buffer, the addition of glyoxylate prevented the measurement of accurate amounts of hydroxypyruvate

This method was used for the SGAT assay in the extracts of $H$. methylovorum GM2 with high HPR and NADH-oxidizing activities. The assay by the coupling methods previously reported was especially difficult for the cell-free extract of this strain. However, using the new method, the SGAT activity was detectable $(0.21$ units $/ \mathrm{mg}$ protein) in the extract prepared from the cells grown on methanol. The decrease in absorbance at $340 \mathrm{~nm}$ was exactly proportional to the amount of SGAT in the cellfree extract until NADH was consumed completely in the reaction mixture. It was also possible by this method to use partially purified HPR free from the NADH-oxidizing activity, which could be obtained by two purification steps [ammonium sulfate fractionation $(50-80 \%$ ) and DEAE-
Sephacel column chromatography].

Compared with the coupling methods, this method is advantageous in the following points. 1. The HPR of $H$. methylovorum GM2 has a higher substrate specificity than the previous coupling enzymes, and its $K m$ for glyoxylate is about 60 -fold higher than that for hydroxypyruvate. 2 . The HPR reaction is irreversible. 3. Even if SGAT activity is measured in samples containing HPR and NADHoxidizing activities at a high level, this end point method is independent of these activities.

\section{References}

1) J. S. Thompson and K. E. Richardson, J. Biol. Chem., 16, 3614 (1967).

2) T. Noguchi, E. Okuno, Y. Tanaka, Y. Minatogawa, K. Okai and R. Kido, Biochem. J., 169, 113 (1978).

3) I. K. Smith, Biochim. Biophys. Acta, 321, 156 (1973)

4) D. W. Rehfeld and N. E. Tolbert, J. Biol. Chem., 247, 4803 (1972).

5) D. Hondred, J. M. Hunter, R. Keith, D. E. Titus and W. M. Becker, Plant Physiol., 79, 95 (1985).

6) P. M. Dunstan, C. Anthony and W. T. Drabble, Biochem. J., 128, 106 (1972).

7) W. Harder, M. M. Attwood and J. R. Quayle, J. Gen. Microbiol., 78, 155 (1973).

8) H. Yamada, S. S. Miyazaki and Y. Izumi, Agric. Biol. Chem., 50, 17 (1986).

9) S. S. Miyazaki, S. Toki, Y. Izumi and H. Yamada, $J$. Ferment. Technol., 65, 371 (1987).

10) S. S. Miyazaki, S. Toki, Y. Izumi and H. Yamada, Eur. J. Biochem., 162, 533 (1987).

$11)$ S. S. Miyazaki, S. Toki, Y. Izumi and H. Yamada, Biochem. Biophys. Res. Commun., 139, 71 (1986).

12) B. L. W. Brock, D. A. Wilkinson and I. King, Can. J. Biochem., 48, 486 (1970).

13) J. King and E. R. Waygood, Can. J. Biochem, 46, 771 (1968)

14) M. A. Blackmore and J. R. Quayle, Biochem. J., 118, 53 (1979).

15) J. S. Thompson and K. E. Richardson, Anal. Biochem., 24, 197 (1968). 